\title{
Detection and identification of etiological agents (Liberibacter spp.) associated with citrus greening disease in Uganda
}

\author{
A. Kalyebi', G. Aisu', I. Ramathani ${ }^{1}$, J. Ogwang ${ }^{1}$, N. McOwen ${ }^{2}$ and P. Russell ${ }^{2}$ \\ ${ }^{1}$ National Crops Resources Research Institute, P.O Box 7084, Kampala, Uganda \\ ${ }^{2}$ Agdia Incorporated, 30380 County Road 6, Elkhart, Indiana 46514, USA
}

Author for correspondence: akalyebi@yahoo.com

\begin{abstract}
Citrus Huanglongbing (HLB), commonly referred to as citrus greening, is one of the major disease challenges of citrus. In Uganda, there was limited information on Liberibacter spp., the causal organisms of HLB disease, and its psyllid vectors despite the presence of HLB symptoms on citrus. The objective of this study was to identify the Liberibacter spp. and psylla vector species responsible for HLB in Uganda. Other native plant species that could be hosts to pathogens and the psyllid vectors, but are not in the citrus genus, were also investigated. A survey was conducted in 15 citrus growing districts, and symptomatic citrus leaf samples collected, as well as citrus psyllid nymphs and adults for isothermal detection of pathogens in the laboratory. Two types of bacterial pathogens responsible for HLB were detected, namely Candidatus Liberibacter africanus (CLaf), known as the African type; and Candidatus Liberibacter asiaticus (CLas), known as the Asian type. CLaf was found in Mukono and Wakiso districts in Central Uganda and in Mbarara in Western Uganda; while CLas was found in Budaka and Tororo districts in Eastern Uganda. Citrus psyllids, which are the major known disease vectors were present in seven out of the fifteen districts. Psyllid vector identification by morphological means indicated Trioza erytreae, the African psyllid to be the insect vector. Psyllids were common on tangerines (66.7\%), Sour Orange (13.3\%) and Rough Lemon (13.3\%); and least on Washington Navel (6.7\%). Three non-citrus plants, Stephania abyssinica (Dill. \& A. Rich) walp var. tomentella (Oliv.) Deils (Menispermaceae), Diospyros mespiliformis (Ebenaceae) and Ficus spp (Moraceae) were found to be alternative host plants for the psyllid.
\end{abstract}

Key words: Candidatus, Diospyros mespiliformis, Psyllids, Trioza erytreae

\section{Introduction}

Citrus is one of the largest fruit crops grown in Uganda together with mango, pineapple, avocado and papaya (UNIDO,
2002). By the 1990s, it was estimated to cover an area of 1,320 hectares, with a total citrus fruit production of about 15,840 metric tonnes. The major citrus growing districts by then were Kamuli, Soroti and 
Lira producing between 2,400 and 3,000 tonnes; followed by Mbale, Iganga and Kumi producing between 1,200 and 1,800 tonnes.

Between 1990 and 2004, citrus production began to decline, and based on symptoms, a disease citrus greening was suspected, although not confirmed due to its resemblance with nutritional disorders, and the complexity of conventional methods in diagnosing the disease (Dr. J. Ogwang, NaCRRI, pers. Comm). Due to suspected citrus greening disease, over the years, a lot of citrus plants were removed and some abandoned, while other trees showed signs of recovery from disease symptoms. Citrus production in Uganda has since remained relatively low with lower than average yields, high production and marketing costs and problems associated with pests and diseases (Sengoba et al., 2002).

Under the Ministry of Agriculture, Animal Industry and Fisheries' Development Strategy and Investment Plan (DSIP), fruit growing, particularly citrus, is prioritised to improve farmers' incomes and nutritional security in the country (MAAIF, 2010). Survey figures showed that about 13,000 farmers were engaged in citrus production in Uganda, with a strong concentration in the eastern region, mainly in the Teso sub-region (NPA, 2007). A number of varieties of citrus were grown in the country, brought from South Africa, Jamaica, Australia, Florida and Hawaii in USA, Israel and Spain. The varieties include among others, Washington Navel, Hamlin, Valencia, Rough Lemon, Sour Orange, Lime, Tangelo, Tangerine and Nova (NaCRRINARO, 1988 unpublished report).

Citrus Huanglongbing (HLB), commonly referred to as citrus greening, is one of the most serious diseases of citrus in the world, responsible for the destruction of several citrus industries in Asia and Africa (da Graca, 1991). The disease is characterised by yellow shoots, mottling, chlorosis resembling zinc deficiency (Fig. 1), twig dieback and reduced fruit size and quality (Capoor et al., 1974). Fruits do not colour properly (remaining greenish yellow instead of uniformly yellow), and usually have a bitter taste. The disease starts small, but with time the number of affected branches on the orchard tree increases until the whole tree is affected.

Two species of phloem-limited bacteria, Candidatus Liberibacter africanus (CLaf) and Candidatus Liberibacter asiaticus (CLas), are considered to be the causal organisms of citrus greening; and more recently, an
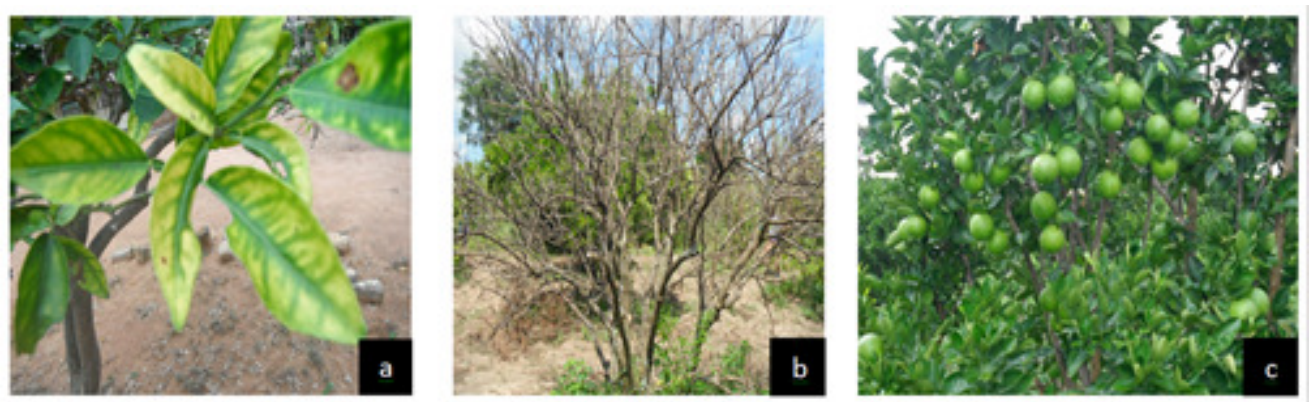

Figure 1. Some symptoms of Citrus Huanglongbing (HLB) observed in farmer's fields in Uganda. (a) zinc-deficiency-like symptoms, (b) severe dieback, both typical of citrus greening disease. and (c) a disease-free citrus plant. 
American strain, Candidatus Liberibacter americanus (CLam) was discovered in Brazil (Texeira et al., 2005).

Although grafting has been found to play an important role in transmission, spread of the disease is almost always due to the presence of its vectors, primarily two species of psyllid insects, the Asian citrus psyllid, Diaphorina citri Kuwayama (Hemiptera: Psyllidae); and the African citrus psyllid, Trioza erytreae (Del Guercio) (Triozidae) (McClean and Oberholzer, 1965; Martinez and Wallace, 1967). The two psyllids are the only known insect vectors of the etiological agents (bacteria) that cause the greening disease.

In nature, CLaf (African HLB) is transmitted primarily by infected $T$. erytreae in the fields (McClean and Oberholzer, 1965) and by grafting infected material onto non-infected material (Lopes and Frare, 2008). CLaf can also be transmitted transovarially by $T$. erytreae (van den Berg et al., 1991-1992). The Asian citrus psyllid D. citri is responsible for transmitting CLas (Asian HLB) (Martinez and Wallace, 1967; Capoor, 1967) and CLam (American HLB) (Yamamoto et al., 2006), with a further transmission by grafting and propagation of infected citrus tissues (Li et al., 2006). Experimentally, T. erytreae has been found to transmit CLas (Mansonie et al., 1976), while D. citri can also transmit CLaf (Lallemand et al., 1986). There is no report to date to indicate whether $T$. erytreae can transmit CLam ever since it was discovered in Brazil. Besides their role in transmission of HLB, psyllid feeding directly causes damage to the citrus and related ornamental crops as they extract sap from the plant, and produce enormous amounts of honey dew (Halbert and
Manjunath, 2004). Psyllids are also known to inject, during feeding, a salivary toxin that stops terminal elongation and causes malformation of leaves and shoots (Michaud, 2004).

Cuscuta (dodder) is also currently considered a host plant for greening as the pathogen can multiply within the plant successfully and has been used to transmit CLas and CLaf (Garnier and Bove, 1983; Olfato et al., 1991). More recently, dodder has also been used to transmit CLam to Nicotiana tabacum L cv xanthi seedlings (Francischini et al., 2007).

There is a wide presence of HLB on the African continent (Aubert et al., 1988). The Indian Ocean islands of Reunion and Mauritius harbour both forms of disease (CLas and CLaf) and both psylla, $T$. erytreae and D. citri. Ethiopia reportedly has both T. erytreae and D. citri and the CLaf HLB organism (Hodkinson, 1980); and more recently, the CLas HLB pathogen (Saponari et al., 2010). Within the East African region, HLB has been reported in Kenya (Bove and Garnier, 1984); Tanzania (Swai, 1988), Rwanda and Burundi (Aubert et al., 1988), with CLaf as causal organism and T. erytreae as vector. There is no information to date on HLB and its vectors in Uganda. Early detection of the citrus greening disease and its associated bacteria in host plants and vector insects is, therefore, essential not only to disease control and containment, but also in reducing its spread to new areas.

This study was undertaken to detect and establish the etiological agents responsible for HLB disease; and the associated vector psylla species in Uganda. 


\section{Materials and methods}

\section{Survey areas and sampling}

Surveys are highly useful to identify foci of infection (Lohr, 1999). Surveys for citrus greening and citrus psyllids were conducted in major citrus producing districts of Uganda between September and December 2012. The districts were Soroti, Serere, Kamuli, Iganga, Tororo, Wakiso, Mukono, Budaka, Bukedea, Arua, Moyo, Mbale, Kumi, Apac and Mbarara. Citrus fields for sampling were randomly selected within the districts and georeferenced by Geographical Positioning System (GPS). Citrus fields included commercial nurseries from both local and improved varieties. Visual assessment of symptom severity was made and leaf samples suspected of citrus greening collected.

According to Li et al. (2009), all phloem-containing plant tissue can be used to sample for Liberibacter infection. In this study, only leaves were used as symptom expression easily becomes evident. Leaves from plants showing greening symptoms were collected, in individual plastic bags, and stored in cool boxes (room temperature) from which they were dispatched to Agdia Laboratories, USA. Twenty leaves (at the exterior of branches) were picked selectively around the tree canopy to ensure sample representativeness. The number of trees sampled per site per district was variable and depended on severity of symptom expression (more severe symptoms indicate highly suspect trees) and frequency of citrus fields (Table 1).

\section{Collection of citrus Psyllids}

A search was conducted for citrus psyllids using two methods, flush observation and stem tapping, targeting particularly nymphs and adults. Young or new flush of citrus and ornamental nursery plants in the target areas, was inspected for presence of yellow-orange eggs, nymphs and emerging or emerged adults. Nymphs were collected with thin forceps; while adult psyllids were collected with an aspirator. Newly emerged adults stay close on leaf surface. A stem was later tapped three times with a white sheet held below it (Hall and Hentz, 2010) and any adults observed on sheet were collected. Both nymphs and adults on symptomatic or asymptomatic trees, were collected. About 20 psyllids constituted a sample.

Psyllid nymphs and adults were put in vials containing $70 \%$ ethanol. Identification of psyllids species was undertaken using adult morphological characters (Martin $e t$ al., 2012). Specimens were deposited at the NARO Insect museum in Kawanda, Uganda for referencing. Some nymphs on leaves were allowed to emerge in netting. Additionally, records of temperature and relative humidity in sampled locations were taken. Scouting for psyllids continued into neighbouring fields (plants) to identify potential alternative host plants for psyllids at least twice at each site.

\section{Psyllid extraction}

Plant tissue and psyllid samples were extracted and tested at Agdia, Inc. Centriguation was done at $6000 \mathrm{rpm}$ for 5 seconds using a benchtop microcentrifuge (USA Scientific, catalogue number 26410016). Leaf samples were prepared by excising sections of the petiole and midvein tissue from each leaf in the sample, using a razor blade. Excised leaf tissue was added to Agdia's proprietary extraction buffer (AMP1) at a 1:5 weightto-volume ratio in a mesh bag (Agdia \#ACC00930); and macerated using a drill press. Extracts were transferred into 1.5 
Table 1. AmplifyRP results of leaf and citrus psyllid samples examined from each of the sampled districts surveyed in Uganda

\begin{tabular}{|c|c|c|c|c|c|c|}
\hline District & S/No. & $\begin{array}{l}\text { Sample } \\
\text { type }\end{array}$ & Variety & $\begin{array}{l}\text { Liberibacter } \\
\text { americanustest }\end{array}$ & $\begin{array}{l}\text { Liberibacter } \\
\text { asiaticustest }\end{array}$ & $\begin{array}{l}\text { Liberibacter } \\
\text { africanustest }\end{array}$ \\
\hline Mukono & 1 & Leaf & Sour Orange & -ve & -ve & -ve \\
\hline Kamuli & 2 & Leaf & - & -ve & -ve & -ve \\
\hline Mbale & 3 & Leaf & Wash. Navel & -ve & -ve & -ve \\
\hline Iganga & 4 & Leaf & Tangelo & -ve & -ve & -ve \\
\hline Bukedea & 5 & Leaf & Hamlin & -ve & -ve & -ve \\
\hline Budaka & 6 & Leaf & Rough Lemon & -ve & -ve & -ve \\
\hline Soroti & 7 & Leaf & Wash. Navel & -ve & -ve & -ve \\
\hline Soroti & 8 & Leaf & Valencia & -ve & -ve & -ve \\
\hline Soroti & 9 & Leaf & - & -ve & -ve & -ve \\
\hline Serere & 10 & Leaf & - & -ve & -ve & -ve \\
\hline Serere & 11 & Leaf & Wash. Navel & -ve & -ve & -ve \\
\hline Serere & 12 & Leaf & Valencia & -ve & -ve & -ve \\
\hline Kumi & 13 & Leaf & Valencia & -ve & -ve & -ve \\
\hline Kumi & 14 & Leaf & - & -ve & -ve & -ve \\
\hline Tororo & 15 & Leaf & Valencia & -ve & -ve & -ve \\
\hline Tororo & 16 & Leaf & Tangelo & -ve & -ve & -ve \\
\hline Kamuli & 17 & Leaf & Valencia & -ve & -ve & -ve \\
\hline Kamuli & 18 & Leaf & Hamlin & -ve & -ve & -ve \\
\hline Wakiso & 19 & Leaf & Rough Lemon & -ve & -ve & -ve \\
\hline Mbarara & 20 & Leaf & Wash. Navel & -ve & -ve & -ve \\
\hline Mbarara & 21 & Leaf & Valencia & -ve & -ve & $+\mathrm{ve}$ \\
\hline Mbarara & 22 & Leaf & Tangerine & -ve & -ve & -ve \\
\hline Mbarara & 23 & Leaf & Hamlin & -ve & -ve & -ve \\
\hline Wakiso & 24 & Psyllid & Rough Lemon & -ve & -ve & $+v e$ \\
\hline Budaka & 25 & Psyllid & Rough Lemon & -ve & +ve & -ve \\
\hline Tororo & 26 & Psyllid & Wash. navel & -ve & +ve & -ve \\
\hline Mukono & 27 & Psyllid & Sour orange & -ve & -ve & $+\mathrm{ve}$ \\
\hline Arua & 28 & Psyllid & Tangerine & & -ve & -ve \\
\hline Arua & 29 & Psyllid & Tangerine & & -ve & -ve \\
\hline Arua & 30 & Psyllid & Tangerine & & -ve & -ve \\
\hline Arua & 31 & Psyllid & Tangerine & & -ve & -ve \\
\hline Моyо & 32 & Psyllid & Sour orange & & -ve & -ve \\
\hline Apac & 33 & Psyllid & Tangerine & & -ve & -ve \\
\hline Apac & 34 & Psyllid & Tangerine & & -ve & -ve \\
\hline Apac & 35 & Psyllid & Tangerine & & -ve & -ve \\
\hline Apac & 36 & Insect spp & Tangerine & & -ve & -ve \\
\hline Apac & 37 & Psyllid & Tangerine & & -ve & -ve \\
\hline Apac & 38 & Psyllid & Tangerine & & -ve & -ve \\
\hline Mukono & 39 & Psyllid & S. abyssinica & & -ve & -ve \\
\hline Mukono & 40 & Leaf & S. abyssinica & & -ve & -ve \\
\hline
\end{tabular}

+ve denotes 'positive' while -ve denotes 'negative' occurrences. 
$\mathrm{ml}$ microcentrifuge tubes, vortexed for 30 seconds, and spun briefly using a bench top micro-centrifuge.

The ethanol was removed from psyllid samples by aspirating using a pipette, and air-dried at room temperature for one hour. Agdia's proprietary extraction buffer (AMP1) and $0.2 \mathrm{~mm}$ glass beads were added to each sample and macerated with a pellet pestle (Fisher Scientific Co., catalogue number 12-141-363). Psyllid samples were homogenised by vortexing for 30 seconds and spun briefly using a bench top micro-centrifuge.

\section{Pathogen detection}

Leaf and psyllid samples were tested for Candidatus Liberibacter asiaticus (CLas), $\mathrm{Ca}$. Liberibacter africanus (CLaf), and $\mathrm{Ca}$. Liberibacter americanus (CLam) using Agdia's new Acceler8 ${ }^{\circledR}$ AmplifyRP ${ }^{\circledR}$ isothermal amplification platform (Sutula et al., 2010; Russell et al., 2011). AmplifyRP utilises recombinasepolymerase amplification (Piepenburg et al., 2006) to promote amplification of target DNA sequences that are labeled with markers during the amplification process, and then detected on lateral flow strips. AmplifyRP has been compared with qPCR and results show equivalency in detection (P. Russell, unpublished data). AmplifyRP is sensitive, effective and has the specificity of PCR-based testing methods (Sutula et al., 2010). Extracted samples were tested for the presence of liberibacter, by adding leaf or psyllid crude extract to CLas, CLaf, and CLam Acceler8 AmplifyRP reactions, and then tested for liberibacter DNA on lateral flow detection strips according to manufacturer's specifications. Results were determined by visually analysing the strips. Leaf tissue and psyllid samples were received on two separate occasions and tested successively. The first test included 23 leaf tissue and 4 psyllid samples.

The second test included 1 leaf tissue and 12 psyllid samples. Based on the results of the initial test, each sample was tested using the CLaf and CLas AmplifyRP tests, but not CLam. DNA purified from known CLaf, CLam, or CLas-infected leaf tissue was mixed with a crude extract prepared from healthy lemon leaf tissue to demonstrate crude extract and AMP1 do not inhibit AmplifyRP isothermal reactions.

\section{Results}

\section{Liberibacter spp. and distribution}

The leaf and psyllid samples revealed the presence of Candidatus Liberibacter asiaticus in Eastern (Tororo, Budaka) and Candidatus Liberibacter africanus in the western (Mbarara) and central regions (Mukono, Wakiso), in Uganda. CLam was not traceable. The two pathogens detected are known to be responsible for Asian and African citrus greening disease, respectively. All leaf samples (except from Mbarara) tested negative for Candidatus Liberibacter spp., in spite of showing symptoms of greening in the field (Table 1). Citrus varieties from which leaf samples were collected were Tangerine (45.4\%), Valencia (18.2\%), Washington Navel $(12.1 \%)$ and Rough Lemon (12.1\%), Hamlin $(9.1 \%)$ and Tangelo (6.1\%). Relatively more psyllid samples (Wakiso, Mukono, Budaka and Tororo) tested positive for Candidatus Liberibacter spp. Psyllid samples from Arua, Moyo and Apac districts tested negative for Candidatus Liberibacter spp (Table 1). Adult morphological characters examined, especially the pale green appearance upon emergence and the 

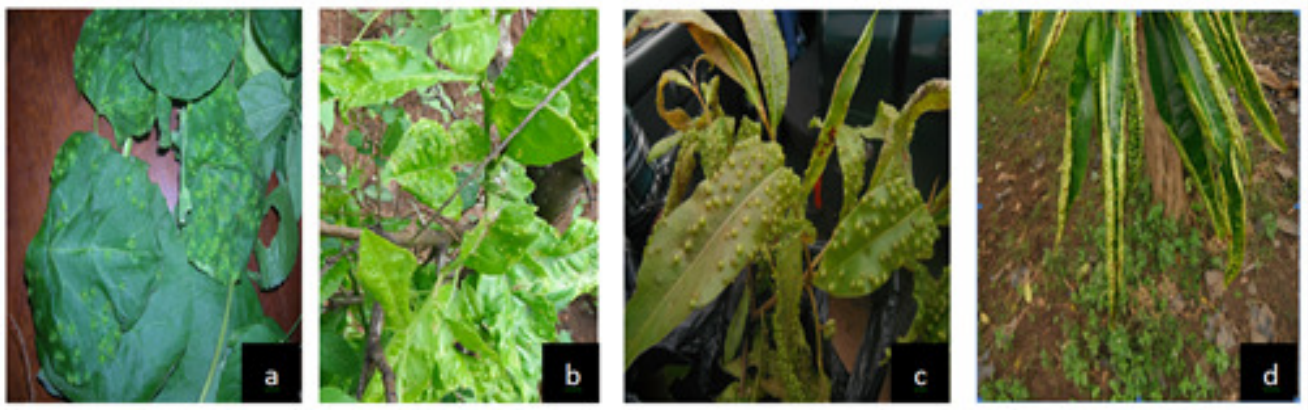

Figure 2. Some non-citrus host plants of a Psyllid vector of Citrus Huanglongbing (HLB) in Uganda. (a) Stephania abyssinica (Menispermaceae) showing pit-galling, leaf distortion and yellowing symptoms as a result of damage by psyllid nymphs, T. erytreae, (b) symptoms of nymph damage on citrus plant, (c) the Jackalberry tree, Diospyros mespiliformis (Ebenaceae), and (d) the Fig tree, Ficus spp (Moraceae), all show symptoms of psyllid pit-galling.

brown/black colour of antennae, feet and head indicated that the psyllid species was the African type Trioza erytreae.

In general, although the symptoms of the disease were evident in almost all locations surveyed, samples of leaves and nymphs collected from all other locations, except Rubongi, (Tororo), Naboa (Budaka), MbaZardi (Mbarara), Kavule (Mukono) and Kawanda (Wakiso), were negative for both types of pathogens.

Generally, the incidence of citrus psyllids was low and psyllids found in 7 out of the 15 districts. A total of $66.7 \%$ of psyllids were collected from tangerines, $13.3 \%$ from both of sour orange and rough lemon, and only $6.7 \%$ from Washington Navel. Mostly, nymphal stages were observed and collected. Adults were observed in most cases soon after emergence, closer to the nymphal case (shell). Citrus psyllids were found only in Apac, Tororo, Budaka, Arua, Moyo, Mukono and Wakiso districts.

\section{Non-citrus psyllid host plants}

Three plants, Stephania abyssinica (Dill. and A. Rich) walp var. tomentella (Oliv.) Deils (Menispermaceae), the Jackalberry tree, Diospyros mespiliformis
(Ebenaceae) and the Fig tree, Ficus spp (Moraceae) (Fig. 2) were found to host psyllids and, hence, identified as alternative host plants for T. erytreae. Stephania abyssinica was recovered in Mukono district with symptoms of psyllid feeding damage (pit-galling, leaf distortion and yellowing of affected foliage) (Fig. 2), with nymphal stages breeding on it. The plant was recovered in a bush closer to citrus fields. Results for this plant were negative for the two species (CLaf and CLas) tested, despite harbouring both nymphal and adult psyllids. Psyllids were also found negative for Liberibacter spp. Diospyros mespiliformis with psyllids was observed in Opuyo, Soroti district; while Ficus spp was found in Kawanda in Wakiso district.

\section{Discussion}

The present study reveals that not only is the African pathogen (CLaf) present, but that the Asian pathogen (CLas) is present in Uganda (Table 1). The two pathogens are responsible for African and Asian forms of greening, respectively. The Asian pathogen has been known to be predominantly Asian in distribution and historically endemic to Mauritius and the 
Reunion islands within Africa. More that both T. erytreae and CLaf do not recently, CLas has been detected in tolerate hot and dry climates (Bove and Ethiopia in sweet orange (Saponari et al., Cassin, 1968; Green and Catling, 1971); 2010). To our knowledge, this is the first thus the disease was restricted to cool report on the occurrence of HLB elevated areas, while D. citri and CLas pathogens (CLaf and CLas) in Uganda, can resist a wide range of climatic and the second record of CLas and this conditions, including high temperatures form of greening outside Mauritius and the (Bove and Cassin, 1968; Bove et al., Reunion, within Africa. CLaf is 1974). predominant in Africa, and only found in Saudi Arabia and Yemen in Asia. It is not clear how the pathogen might have moved to Uganda but with the ever increasing international trade, travel and immigration, the probability of unintentional introduction is high. Control of this pathogen and, therefore, HLB disease is usually through quarantine to make sure that the bacteria is not introduced or established (da Graca and Korsten, 2004).

Given their nature, the observed distribution of the two pathogens (CLaf and CLas) in Uganda may be influenced by climatic conditions particularly temperature. Whereas CLas was detected in Eastern Uganda where it is relatively hot, CLaf was found in western and central Uganda where conditions are relatively warm and cool. Average temperatures in Eastern Uganda range from 27 to $35^{\circ} \mathrm{C}$ while that of central and western region from 25 to $30{ }^{\circ} \mathrm{C}$, respectively. These temperature differences could easily be responsible for distribution of pathogens and disease as previous work has shown CLam, CLaf, and CLas have different temperature tolerances. CLas is capable of thriving at temperatures $>35^{\circ} \mathrm{C}$, while CLam could not be detected in plants maintained in temperatures above $32{ }^{\circ} \mathrm{C}$ (Hoffman, et. al., 2013). CLaf is particularly temperature sensitive and thrives only in a narrow range of $22-25{ }^{\circ} \mathrm{C}$. This corroborates with earlier studies that found

Although greening in Africa and Yemen is known to be transmitted under natural conditions by $T$. erytreae (McClean and Oberholzer, 1965; EPPO/ CABI, 1996a); and in Asia by Diaphorina citri (Capoor et al., 1967; EPPO/CABI, 1996b), it is possible that either species could transmit either of the pathogens (Manssonie et al., 1976; Lallemand et al., 1986). Further screening and identification of foci psyllids from a wider area needs to be undertaken to rule out the possible introduction of $D$. citri. The activity, the population dynamics and population genetics of both the psyllid and liberibacter species also need to be understood.

The fact that many leaf samples tested negative, in spite of showing symptoms of greening, may be due either to lower concentrations or uneven distribution of pathogens within citrus tissues or hosts (McClean, 1970; Huang, 1979). Typically, if a plant is infected and displays symptoms, then the titer of bacteria is high enough to be detected by AmplifyRP. Uneven distribution of pathogens sometimes makes detection difficult while in some cases, nutritional deficiencies also appear to resemble HLB-infection symptoms and various tests need to be carried to confirm.

Based on severity of symptoms, greening was much more severe in Eastern (e.g. mean severity 4.6 in Mbale, 3.1 in Serere) than Central and Western (1.6 in Iganga, 2.7 in Mbarara). This 
relates well with previous findings that CLas is more severe than CLaf although disease severity may be a function of other factors such as nutritional status of the soil, age of the trees and whether one strain or a combination of pathogens is present. There was no plant or single location where the two pathogens were found to be co-existent.

The identification of three non-citrus host plants for the citrus psyllids, (Fig. 2) means that control efforts for psyllids in Uganda should be widened beyond citrus to avoid re-infestations from these alternative hosts. Regular monitoring of both citrus and non-citrus hosts therefore needs to be undertaken. There is need to understand the vector-pathogen relationship of psyllid vectors and pathogens to facilitate control and further spread of HLB disease in Uganda through regular monitoring. Greening can be introduced into an orchard with infected planting material or through spread by psyllids from neighboring infected orchards. At the moment, measures need to be undertaken to screen both citrus rootstock and scions before grafting to prevent further spread of disease to areas where it does not exist. Attempts should also be reinforced to control citrus psyllids, the known insect vectors of Candidatus Liberibacter spp., to prevent further spread of disease and prevent introduction of pathogens to areas where psyllids exist but no incidence of infection has occurred.

\section{Acknowledgement}

This work was made possible with funds from the NARO Agricultural Technology and Agribusiness Advisory Services (ATAAS) Project funded by the World Bank. We wish to acknowledge the contributions of Mildred Alanyo, Phyllis
Kasambula and James Nsubuga during field surveys. Thanks to Deborah GrothHelms at Agdia, for the prompt processing and testing of samples, and to Olivia Wanyana of Makerere University, Department of Botany, for identifying the host plant samples.

\section{References}

Aubert, B., Garnier, M., Cassim, J.C. and Bertin, Y. 1988. Citrus greening in East and West African countries south of the Sahara. In: Proceedings of the $10^{\text {th }}$ Conference of the International Organization of Citrus Virologists. pp. 226-230.

Bove, J.M., Calavan, R.C., Capoor, S.P., Cortez, R.E.and Schwarz, R.E. 1974. Influence of temperature on symptoms of California Stubborn, South Africa greening, India citrus decline, and Philippines leaf mottling diseases. In: L.G. Weathers, and M. Cohen (Eds). Proceedings of the $6^{\text {th }}$ Conference of the International Organization of Citrus Virologists pp. 12-15.

Bove, J.M. and Cassin, J.P. 1968. Problemes de l'agrumiculture reunionnaise. Compte-rendu de mission, Doc. IRFA. 50p.

Bove, J.M. and Garnier, M. 1984. Citrus greening and psylla vectors of the disease in the Arabian Peninsula. In: Garnsey, S.M., Timmerand, L.W. and Dodds, J.A. (Eds). Proceedings of the $9^{\text {th }}$ Conference of the International Organization of Citrus Virologists, University of California, Riverside, CA. pp. 109-114.

Capoor, S.P., Rao, D.G. and Viswanath, S.M. 1967. Diaphorina citri Kuwayama, a vector of citrus greening disease of citrus in India. 
Indian Journal of Agricultural Science 37: 572-6.

Capoor, S.P., Rao, D.G. and Viswanath, S.M. 1974. Greening disease of citrus in the Deccan Trap Country and its relationship with the vector, Diaphorina citri Kuwayama, pp. 4349. In: Weathers, L.G. and Cohen, M. (Eds). Proceedings of the $6^{\text {th }}$ Conference of the International Organization of Citrus virologists. University of California, Richmond.

Da Graca, J.V. 1991. Citrus greening. Ann. Rev. Phytopathology 29:103136

da Graça, J. V. and Korsten, L. 2004. Citrus huanglongbing: review, present status and future strategies, pp 229245. In: Naqvi, S.A.M.H. (Ed.). Diseases of fruit and vegetables, Vol. 1. Kluwer Academic, The Netherlands.

EPPO/CABI 1996a. Trioza erytreae. In: I.M. Smith, D.G. McNamara, P.R. Scottand M. Holderness(Editors). Quarantine pests for Europe. $2^{\text {nd }}$ Edition. CAB International, Wallingford, UK.

EPPO/CABI, 1996b. Diaphorina citri. In: I.M. Smith, D.G. McNamara, P.R. Scott and M. Holderness. Quarantine pests for Europe. $2^{\text {nd }}$ Edition, $\mathrm{CAB}$ International, Wallingford, UK.

Francischini, F.J.B., Oliveira. K.D.S., Astua-Monge. G., Novelli, A., Lorenzino, R., Matiolli, C., Kemper, E., Da Silva, A.C.R. and Kitajima, E.W. 2007. First report on the transmission of Candidatus Liberibacter americanus from citrus to Nicotiana tabacum cv. Xanthi. Plant Disease 91: 631.

Garnier, M. and Bove, J.M. 1983. Transmission of the organism associated with the citrus greening disease from sweet orange to periwinkle by dodder. Phytopathology 73: 1358-1363.

Garnier, M., Gao, S.J, He, Y.E., Villechanoux, S., Gandar, J. and Bove, J.M. 1991. Study of the Greening Organism (GO) with monoclonal antibodies: Serological identification, morphology, serotypes and purification of the GO. pp. 428-435. In: Proc. Conf. Int. Organ. Citrus Virol. $11^{\text {th }}$, University of California, Riverside, CA. Green, G.C. and Catling, H.D. 1971. Weather induced mortality of the citrus psylla Trioza erytreae (Del Guercio), a vector of greening virus in some citrus producing area of southern Africa. Agric. Meteorology 8:305307.

Halbert, S.E. and Manjunath, K.L. 2004. Asian citrus psyllids (Sternorrhyncha: psyllidae) and greening disease of citrus: A literature review and assessment of risk in Florida. Florida Entomologist 87:330-353.

Hall, D.G. and Hentz, M.G. 2010. Sticky trap and stem-tap sampling protocols for the Asian citrus psyllid (Hemiptera: Psyllidae). Journal of Economic Entomology 103 (2):541-549.

Hodkinson, I.D. 1980. Present day distribution patterns of the Holoarctic Psylloidea (Homoptera: Insecta), with special reference to the origin of the Nearctic fauna. Journal of Biogeography 7:127-146.

Hoffman, M.T., Doud, M.S., Williams, L. 2013. Heat treatment eliminates 'Candidatus liberibacter asiaticus from infected citrus trees under controlled Conditions. Phytopathology Journal 103(1):15-22.

Huang, C.H. 1979. Distribution of Likubin pathogen in Likubin-affected citrus 
plant. Journal of Agricultural Research of China 28: 29-33.

Lallemand, J., Fos, A. and Bove, J.M. 1986. Transmission de la bacteria associe a la forme africaine de la maladie du "greening" par le psylle asiatique Diaphorina citri Kuwayama. Fruits 25:455-465.

Li, W. Hartung, J.S. and Levy, L. 2006. Quantitative real-time PCR for detection and identification of Candidatus Liberibacter spp. Associated with citrus Huanglongbing. Journal of Microbiological Methods 66:104-115.

Li, W., Levy, L. and Hartung, J.S. 2009. Quantitative distribution of 'Candidatus Liberibacter asiaticus' in citrus plants with Huanglongbing. Phytopathology 99:139-144.

Lohr, S.L. 1999. Sampling: Design and analysis. Pacific Grove, California: Duxbury Press. 450 pp. $1^{\text {st }}$ ed.

Lopes, S.A. and Frare, G.F. 2008. Graft transmission and cultivar reaction of citrus to Candidatus Liberibacter africanus. Plant Disease 92:21-24.

MAAIF, 2010. Agriculture for food and income security: Agriculture Sector Development Strategy and Investment Plan 2010/11- 2014/15. Ministry of Agriculture, Animal Industry and Fisheries, Uganda.

Manssonie, G., Garnier, M. and Bove, J.M. 1976. Transmission of Indian citrus decline by Trioza erytreae, the vector of South African greening. In: Calavan, E.C. (Ed.). Proceedings of the $7^{\text {th }}$ Conference of the International Organization of Citrus Virologists, pp. 18-20. University of California Riverside, USA.

Martin, K.W., Hodges, A.C. and Leppla, N.C. 2012. Citrus pests. www.
Idtools.org/id/citrus/pests/fact sheet.php. Accessed August 2012.

Martinez, A.L. and Wallace, J.M. 1967. Citrus leaf mottle-yellows disease in the Philippines and transmission of the causal virus by a psyllid Diaphorina citri. Plant Dis. Reptr 51:692-695.

McClean, A.P.D. 1970. Greening disease of sweet orange: Its transmission in propagative parts and distribution in partially diseased trees. Phytophylactica 2:263-8.

McClean, A.P.D. and Oberholzer, P.C.J. 1965. Citrus psylla, a vector of the greening disease of sweet orange. South African Journal of Agricultural Science 8:297-8.

Michaud, J.P. 2004. Natural mortality of Asian citrus psyllids (Homoptera: Psyllidae) in central Florida. Biological control 29:260-269.

NPA, 2007. National Planning Authority, Ministry of Finance, Planning and Economic Development, Uganda.

Olfato, R.B., Horadura, L.E., Magnaye, L.V. and Gonzalez, C.I. 1991. Transmission of the organism associated with citrus greening disease from szikom to periwinkle by dodder in the Philippines. In: Chung, K. and Osman, S.B. (Eds.). Proceedings of the $6^{\text {th }}$ International Asia pacific workshop on Integrated Citrus Health Management. Kuala Lumpur, Malaysia.

Piepenburg, O., Williams, C.H., Stemple, D.L. and Armes, N.A. 2006. DNA detection using recombination proteins. PLoS Biol 4 (7): e204. DOI: 10.1371/ journal.pbio.004020.

Russell, P.F., McOwen, N. and Bohannon, S. 2011. Isothermal detection of Huanglongbing in psyllids and citrus tree samples. Proceedings of the $2^{\text {nd }}$ International Conference on 
Huanglongbing, Orlando, Florida, Saillard, C. and Bove, J.M. 2005. First USA. pp. 83-86.

Saponari, M., De Bac, G., Breithaupt, J., Loconsole, G., Yokomi, R.K. and Catalano, L. 2010. First report of Candidatus Liberibacter asiaticus associated with Huanglongbing in sweet orange in Ethiopia. Plant disease 94 (4): 482. http://dx.doi.org/ 10.1094/PDIS-94-4- 0482A. report of a Huanglongbing-like disease of citrus in Sao Paulo state, Brazil and association of a new Liberibacter species, "Candidatus Liberibacter americanus" with the disease. Plant disease 89:107.

UNIDO, 2002. United Nations Industrial Development Organization, Report 2002.

Sengoba, T., Hakiza, J.J., Kalunda, P., Van den Berg, M.A., van Vuuren, S.P. and Ameo, M. and Ogwang, Y. 2002. Introduction and evaluation of improved Citrus and Mangoes through Farmers Field Schools. Project Supported by NARO/DFID COARD Project.

Sutula, C., Russell, P. and McOwen, N. 2010. AmplifyRP: An incredibly versatile, rapid isothermal nucleic acid amplification system. $25^{\text {th }}$ annual Tomato Disease Workshop. UFL/ IFAS GCREC, Wimauma, FL, USA.

Swai, I.S. 1988. Citrus diseases in Tanzania. Acta Horticulturae 218: 329-331.

Texeira, D.C., Ayres, J., Kitajima, E.W., Deacon, V.E. 1991-1992. Studies on greening disease transmission by the citrus psylla Trioza erytreae (Hemiptera: Triozidae). Israel Journal of Entomology 25-26:51-56.

Yamamoto, P.T., Felippe, M.R. and Garbim, L.F. 2006. Diaphorina citri (Kuwayama) (Hemiptera: Psyllidae): vector of the bacterium 'Candidatus Liberibacter americanus'. In: Ayres, A.J., Nogueira, E., Parra, J.R.P., Bove, J.M., Machado, M.A. and Bargamaschi, O. (Eds.). Proceedings of the Huanglongbing Greening International Workshop, Ribeirao Preto, Brazil. Fundecitrus 25-6.

Danet, L., Jagoueix-Eveillard, S., 